\title{
Education/obrazovanie as an experience of an encounter
}

\section{Theses in English and Russian, Long-distance video conference 1 and 2 (Тезисы на} английском и на русском, Дистанционные видео конференции 1 и 2)

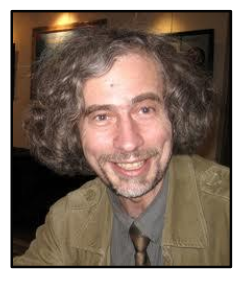

\author{
Alexander Lobok \\ Doctor of Psychology, Professor, Department of General Psychology, Ural State Pedagogical \\ University, Yekaterinburg, Russia \\ Александр Лобок, доктор психологических наук, профессор кафедры общей психологии \\ Уральского государственного педагогического университета, г. Екатеринбург
}

\begin{abstract}
Experience is something which cannot be received like knowledge from someone else. Experience is what you live through yourself. Therefore experience is something that belongs only to the person him/herself. It is his/her absolutely individual and irreplaceable testament to reality. Every person without exception has HIS/HER absolutely unique experience of the encounter with culture (= experience of education/obrazovanie). The multiple trajectories of this inner experience are the most profound and significant result of the educational process. And the increase in the diversity of such trajectories of inner experience can be seen as a key indicator of what we call the quality of education/obrazovanie. Video 1 https://vimeo.com/88029209
\end{abstract}

Video 2 https://vimeo.com/88032506

"The dialogic meeting of two consciousnesses in the human sciences [and education/obrazovanie]." Bakhtin (1986, p.123)

1. The Russian term for education, obrazovanie, is literally a process of forming a new reality, a new entity. It is precisely in this sense that we talk about the formation of mountains, continents, planets... But also with regard to the formation of a person, i.e., education. The education/obrazovanie of a person is the formation of his/her personality, his/her "I", his/her individuality IN RELATION TO CULTURE. Thanks to the process of education/obrazovanie a person discovers the ability to see and feel the pulsation of his/her "l", his/her individuality within the dimension of one or another culture. Not "to appropriate culture" (culture, fortunately, cannot be "appropriated" or "acquired"), but to discover ONESELF in relation to a culture. And this means to enter into a dialogue with the culture. Not to subordinate oneself to a culture, not to reproduce a culture, but to build relations of partnership with a culture. Such is the nature of ENCOUNTER.

2. An educated (obrazovanny, formed) person is one who has established him/herself as an individual personality within the dimensions of a given culture or cultures. This is a person who has had an ENCOUNTER with the given culture in one way or another. In other words, an educated person is one who has acquired the ability to enter into a dialogue with culture (as a DIFFERENT SUBJECTIVITY/AGENCY). The experience of encounter is nothing more than the experience of 
dialogue, i.e., experience of the distance at which two subjectivities/agencies are being cultivated: the subjectivity/agency of a person and the subjectivity/agency of culture. An educated (obrazovanny, formed) person is not one who tries to identify with the culture, in which [s] he is immersing, not one who subordinates him/herself to the culture, not one who reproduces the culture, not one who acquires the culture, but one who tries to create a certain self-distance from the culture which [s] he is entering into dialogue with. That is why an encounter with the culture becomes for him/her a condition for the development of his/her self, his/her personality. But, on the other hand, an encounter with each individual self becomes significant for the culture as well. It is because the culture encounters a multitude of personal worlds that the culture stays alive and, in each of these worlds, is refracted in its own way. The culture remains alive through the diversity of the PERSONAL MIRRORS in which it is reflected; the greater the number of such personal mirrors, the more voluminous and productive is the life of the culture.

3. The education, obrazovanie, (or formation) of a person always involves EXPERIENCE. It is experience in existentially living through (prozhivanie) those "formational conditions" (i.e., "educational conditions") in which a person turns out to be placed. Adults think that the point of education is to "teach" a child something. Or to create conditions for him/her to "learn" something. However, in actual fact the "dry residue" of the educational movement (and, in this sense, the REAL RESULT of the educational movement) does not in any way involve what the child "has learned" (not, at least, in the sense of mastering or acquiring as a result of any initiatives). Rather, it comprises what existential experience of living in the world of education/obrazovanie he has been through - what experience in venturing beyond the limits of cognition of his/her own self, essence or identity. Of course, education/obrazovanie is the experience whereby a person constructs his/her "cultural body", his/her "cultural shell". But at the same time - and this is possibly the MAIN POINT of education/obrazovanie - it involves experience of existentially inhabiting one's cultural body in the process of its formation, experience of enduring the profound conflict between the uneducated self and the educated self, experience of discovering one's self within the dimensions of the educational (obrazovatel'ny, forming) process under way, and experience of reflecting oneself in this process of personal educational (obrazovatel'ny, forming) development.

4. Experience is something which cannot be received like knowledge from someone else. Experience is what you live through yourself. Therefore experience is something that belongs only to the person him/herself. It is his/her absolutely individual and irreplaceable testament to reality. Every person without exception has HIS/HER absolutely unique experience of the encounter with culture (= experience of education/obrazovanie). The multiple trajectories of this inner experience are the most profound and significant result of the educational process. And the increase in the diversity of such trajectories of inner experience can be seen as a key indicator of what we call the quality of education/obrazovanie.

Translated from Russian by David Foreman, University of Waikato, New Zealand

Edited in English by Eugene Matusov, University of Delaware, USA and Mikhail Gradovski, University College of Telemark, Norway 
«Диалогическая встреча двух сознаний в гуманитарных науках [и в образовании].», М.М. Бахтин, «К методологии гуманитарных наук»

1. Образование - это процесс формирования некоей новой реальности, некоей новой сущности. Именно в этом смысле мы говорим об образовании гор, материков, планет... Но и об образовании человека тоже. Образование человека - это образование его личности, его Я, его индивидуальности ПО ОТНОШЕНИЮ К КУЛЬТУРЕ. Благодаря процессу образования человек обнаруживает способность увидеть и почувствовать пульсацию своего Я, своей индивидуальности в пространстве той или иной культуры. Не «присвоить культуру» (культуру, к счастью, «присвоить» нельзя) но обнаружить СЕБЯ по отношению к культуре. А это значит вступить с культурой в диалог. Не подчинить себя культуре, но построить с культурой партнерские отношения. Это и есть состояние ВСТРЕЧИ,

2. «Образованный человек» - это человек, который состоялся как личность в пространстве той или иной культуры, тех или иных культур. Это человек, который в той или иной мере ВСТРЕТИЛСЯ с культурой. Это значит, что образованный человек - это человек, который обрел способность вступить с культурой (как ИНОЙ СУБЪЕКТНОСТЬЮ) в некий диалог. Опыт встречи - это именно опыт диалога. То есть опыт дистанции, на которой возделываются две субъектности: субъектность человека и субъектность культуры. Образованный человек - это не человек, который пытается отождествиться с культурой, в которую он погружается, не человек, который подчиняет себя культуре, но человек, который пытается простроить некую Я-дистанцию с той культурой, с которой он вступает в диалог. Именно потому встреча с культурой оказывается для него условием развития его Я, его персональности. Но, с другой стороны, и для культуры оказывается значимой встреча со всяким отдельным Я. Культура жива именно тем, что она встречается с множеством личностных миров, и в каждом из этих миров преломляется посвоему. Культура жива многообразием ЛИЧНОСТНЫХ ЗЕРКАЛ, в которых она отражается, и чем больше такого рода личностных зеркал, тем объемнее и продуктивнее жизнь культуры.

3. Образование человека - это всегда ОПЫТ. Опыт экзистенциального проживания тех «образовательных условий», в которые оказывается поставлен человек. Взрослые думают, что смысл образования заключается в том, чтобы ребенка чему-то «научить». Либо создать условия для того, чтобы он чему-то «научился». Однако на самом деле «сухой остаток» образовательного движения (и, в этом смысле, ИСТИННЫЙ РЕЗУЛЬТАТ образовательного движения) заключается вовсе не в том, чему ребенок «научился» (то есть не в том, что он освоил или усвоил в результате чьих бы то ни было инициатив), но в том, какой экзистенциальный опыт проживания себя в мире образования он осуществил. Какой опыт выхода на пределы осознания своего Я, своей сущности, своей «самости».

Конечно, образование - это опыт строительства человеком своего «культурного тела», строительства своей «культурной оболочки». Но одновременно с этим - и, возможно, это и есть САМОЕ ГЛАВНОЕ В образовании - это опыт экзистенциального проживания своего становящегося культурного тела, опыт проживания глубинного конфрликта себя-необразованного с собой-образованным, опыт обнаружения своего Я в пространстве происходящего образования и опыт рефлексии себя в этом процессе своего образовательного развития. Опыт - это то, что нельзя получить как знание от кого-то другого.

4. Опыт - это то, что ты проживаешь ты сам. Поэтому опыт - это то, что принадлежит только самому человеку. Это его абсолютно индивидуальное и незаёмное проживание реальности. У каждого без исключения человека СВОЙ, абсолютно уникальный опыт встречи с культурой (=опыт 
образования). Множество траекторий этих внутренних опытов - это и есть наиболее глубокий и значительный результат образовательного процесса. А увеличение многообразия такого рода траекторий внутреннего опыта можно рассматривать как ключевой показатель того, что мы называем качеством образования.

\section{(c) $)$ EY}

Articles in this journal are licensed under a Creative Commons Attribution 3.0 United States License.

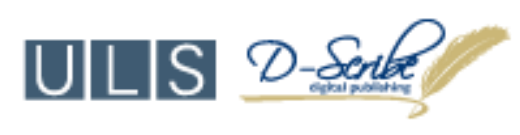

This journal is published by the University Library System, University of Pittsburgh as part of its D-Scribe Digital Publishing Program and is cosponsored by the University of Pittsburgh Press. 


\section{Long-distance video conference\#1}

\section{The Bakhtinian International Conference, Hopuhopu, New Zealand, January 15, 2014}

Participants: Alexander Lobok (presenter, from Yekaterinburg, Russia), Eugene Matusov (USA, interpreter), Pam Harding (chair, New Zealand), Mikhail Gradovski (Norway), Jeremy (Jay) Kedian (New Zealand), Craig Brandist (UK), Theodor Taptiklis (New Zealand).

Duration: 01:26:01

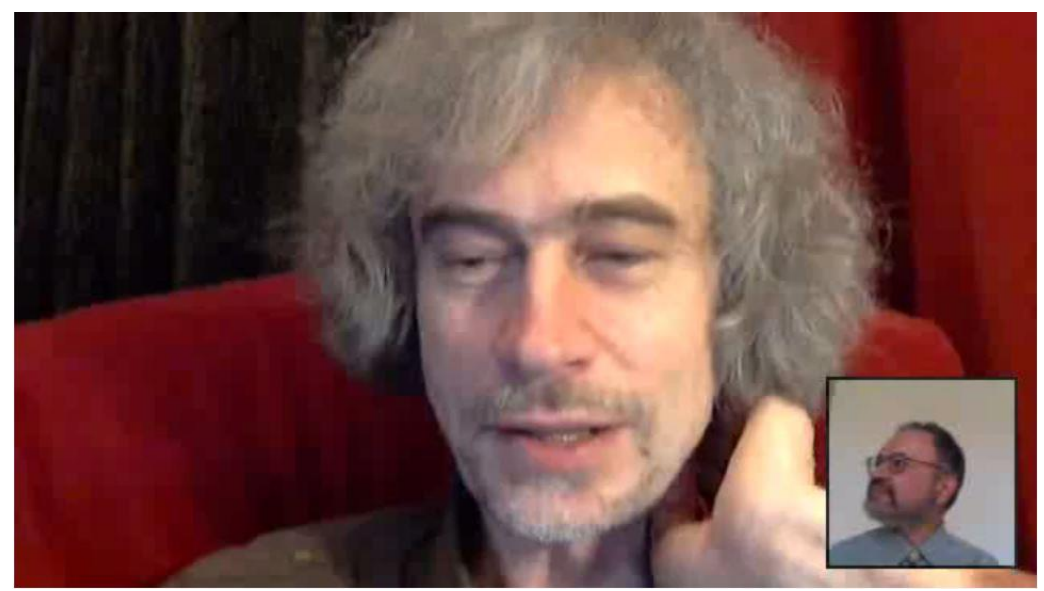

Video 3 https://vimeo.com/88029209 (click to watch)

\section{Long-distance video conference\#2}

\section{University of Waikato, Hamilton, New Zealand, February 12, 2014}

Participants: Alexander Lobok (presenter, from Yekaterinburg, Russia), Eugene Matusov (USA, interpreter), Pam Harding (New Zealand), Jeremy (Jay) Kedian (New Zealand), Richard Heraud (New Zealand), Theodor Taptiklis (New Zealand), Charles Bisley (New Zealand), Jayne White (New Zealand), Ana Marjanovic-Shane (USA, from Philadelphia).

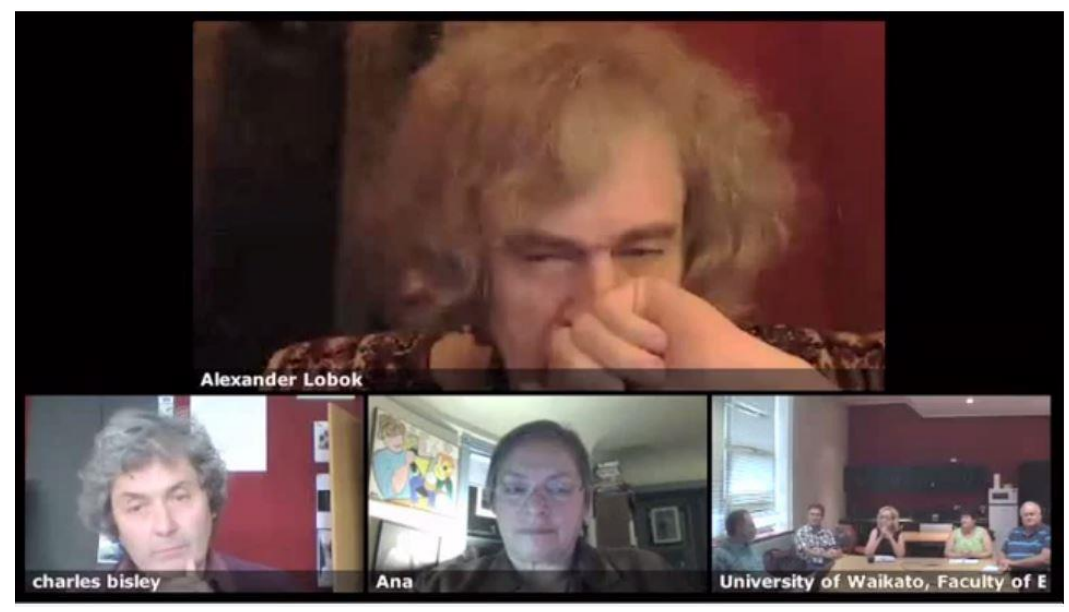

Video 4 https://vimeo.com/88032506 (click to watch) 